\title{
Genotyping of Drought Tolerant Upland Land Races of Rice Using SDS-PAGE of Total Seed Storage Protein
}

\author{
S. K. Tripathy* and Sasmita Dash
}

Sinha Molecular Breeding Laboratory, Dept. of Plant Breeding and Genetics, College of Agriculture, OUAT, Bhubaneswar, Odisha (751 003), India

\section{Article History}

Manuscript No. AR977

Received in $16^{\text {th }}$ October, 2014

Received in revised form $11^{\text {th }}$ May, 2015

Accepted in final form 29 $9^{\text {th }}$ May, 2015

\section{Correspondence to}

*E-mail: swapankumartripathy@gmail.com

\section{Keywords}

Upland rice, seed protein profiles, genotyping, genetic diversity

\begin{abstract}
A set of drought tolerant local land races of Odisha (India) including popular high yielding upland rice genotypes were characterized using total seed storage protein fingerprinting. 15 out of 19 scorable polypeptide bands with molecular weights ranging from 26.0 to $123.0 \mathrm{kD}$ revealed wide polymorphism (78.94\%) based on presence/ absence of bands. Besides, the polypeptide markers differed in staining intensity, migration velocity and their frequency among the test genotypes. Seed protein profiles showed wide genetic variation among the tested materials, with similarity coefficients varying 0.47 to 1.00 . Six test genotypes togatherly and four paired genotypes showed complete homozygosity (S.I. $=100 \%$ ) for seed storage protein profile. While, Khursudi $($ Av. S.I. $=0.58)$ followed by Khandagiri (Av. S.I. $=0.62)$ and Nagina $22($ Av. S.I. $=0.69)$ had high genetic dissimilarity from most of the varieties. Cluster analysis revealed nine distinct groups of rice varieties at the similarity coefficient 0.91 . Khursudi maintained high genetic distance from Bastul, Brahmanaki, Zhu 11-26 and Vandana. Whereas, N22 showed appreciable genetic dissimilarity from Khandagiri and Zhu 11-26. Besides, Khandagiri was shown to be genetically distant from Asumakunda, Brahmanaki, Hiran, Khursudi, N22, Padarabank, Anjali and Vandana. Khandagiri is a popular high yielding widely adaptable improved upland variety. Drought tolerance may be introgressed into Khandagiri using highly divergent drought tolerant donors e.g., N22, Khursudi, Vandana and Zhu 11-26 through recombination breeding. Besides, a few genotypespecific polypeptide bands are useful for genotype identification.
\end{abstract}

\section{Introduction}

Odisha is the genetic paradise of rice and its Jeypore tract (Koraput) is considered as the home for a rich diversity of landraces (Ramiah, 1953) owing to wealth of genes they contain. The traditional upland rice of Odisha is characterized by early maturity, medium to short height, thin culm, few tillers, small panicles, and often red/light red kernel (Sharma et al., 2000). However, it may not be possible to distinguish two varieties by morphological characteristics alone. Therefore, there is a need for a new tool for genotyping. The electrophoretic analysis using seed storage proteinsisaminable for study of evolutionary relation of several crop plants (Ravi et al., 2003). Besides, the polypeptide banding pattern of seed storage proteins can reveal a considerable degree of polymorphism and homology across taxa owing to simple genetic control subject to minimum environmental influence compared to isozyme and soluble proteins. The polypeptide banding pattern based on SDS-PAGE of seed proteins does not require amplification or radio-isotope labeling. In spite of the fact that, the degree of intra-specific variation exhibited by polypeptide banding pattern in SDS-PAGE is lower as compared to primer based/probe-DNA hybridization based genome profiling; this simpler and cheaper technique could be a viable alternative to study genetic variation and genetic amelioration in crop plants. In the present study, therefore, an attempt has been made to use the potential of SDS-PAGE of total seed storage proteins in genotype profiling of a set of drought tolerant land races including few early maturing rice varieties for varietal identification and genetic diversity.

\section{Materials and Methods}

A set of 18 selected drought resistant local land races of Odisha (India), eight drought tolerant improved cultivars (Sasmita, 2014) and three popular high yielding upland genotypes (Khandagiri, Mandakini and Sneha) were characterized using 
total seed storage protein fingerprinting (Table 1). Five seeds (brown rice) from single plant of each test genotype were ground to fine powder with mortar and pestle. Total seed storage protein was extracted with extraction buffer $(0.25 \mathrm{M}$ Tris- $\mathrm{HCl}$ (pH 6.8), 4\% SDS, $10 \%$ glycerol, $5 \% \beta$-mercaptoethanol and $8 \mathrm{M}$ urea $)$ and denatured with a cracking buffer $(0.125 \mathrm{M}$ Tris$\mathrm{HCl}, \mathrm{pH} 6.8,4 \%$ SDS, $20 \%$ glycerol; $10 \%$ 2-Mercaptoethanol; $0.1 \%$ bromophenol blue) at $100{ }^{\circ} \mathrm{C}$ for $20 \mathrm{sec}$ in hot water bath (Tripathy et al., 2015). Total seed protein was then analysed through $12.5 \%$ polyacrylamide gel in a mini vertical electrophoresis apparatus (Tarsons Ltd., India) following Laemmli (1970) with minor modifications at $100 \mathrm{~V}$ for four hours. Each set of genotypes were run twice simultaneously on two separate gels under similar electrophoretic conditions to check up reproducibility. After electrophoresis, the gels were stained with silver staining technique following Blum et al. (1987) with minor modification.

The presence and absence of bands were scored as 1 and 0 respectively to determine variation among genotypes. The gels were placed on Gel Documentation System (Fire ReaderUvtec, Cambridge, UK) for assessment of banding pattern and photographed. The relative mobility (Rm-value) of each protein band was calculated using software of the Gel doc system. The molecular weights of the dissociated polypeptides were determined by using molecular weight marker of protein standards which consisted seven standard proteins of known molecular weight i.e., carbonic anhydrase ( $29 \mathrm{kD})$, ovalbumin (43 kD), bovine serum albumin (66 kD) and phosphorylase-b (97.4 kD).

The genotypes were categorized according to polypeptide banding pattern of seed storage protein. The binary data matrix for presence (1)/absence (0) of bands were analysed using NTSYS Software programme (NTSYSpc 2.02e) to estimate Jaccard's similarity coefficient (Jaccard, 1908) values and clustering of genotypes (dendrogram) was carried out using Unweighted Paired Group Method with Arithmetic means (UPGMA)-phenograms (Sokal and Michener, 1958) employing Sequential Agglomerative Hierarchic and Nonoverlapping clustering (SAHN). The entire research was carried out at Dept. of Plant Breeding and Genetics, College of Agriculture, OUAT, and Bhubaneswar, India during the year 2013-14.

\section{Results and Discussion}

Glutelin (acid and/or alkali soluble) is the major seed storage protein $(80 \%)$ in rice endosperm compared to globulin (salt soluble) and prolamin (alcohol soluble) (Cagampang et al., 1966). In rice, two groups of polypeptide complexes e.g., 22-to $23 \mathrm{kD}$ and 37-to $39 \mathrm{kD}$ constitute the major glutenin fractionwhich are formed through post-translational cleavage

\begin{tabular}{|c|c|c|c|}
\hline $\begin{array}{l}\text { Sl. } \\
\text { no. }\end{array}$ & Genotype & $\begin{array}{l}\text { Source (Village/ } \\
\text { block, district of } \\
\text { Odisha) }\end{array}$ & Remark(s) \\
\hline 1. & $\begin{array}{l}\text { Asuma } \\
\text { kunda }\end{array}$ & $\begin{array}{l}\text { Dahani, Gudari, } \\
\text { Raigada }\end{array}$ & Upland local land race \\
\hline 2. & Bastul & $\begin{array}{l}\text { Pagarpani, } \\
\text { Nuapada }\end{array}$ & - do- \\
\hline 3. & Brahmanaki & CRRI, Cuttack & - do- \\
\hline 4. & Browngora & CRRI, Cuttack & - do- \\
\hline 5. & Dular & $\begin{array}{l}\text { Somanathpur, } \\
\text { K.Gumma, } \\
\text { Malkangiri }\end{array}$ & - do- \\
\hline 6. & Hiran & $\begin{array}{l}\text { Dhungiamunda, } \\
\text { Sinapali, Nuapada }\end{array}$ & - do- \\
\hline 7. & Kanding & $\begin{array}{l}\text { Binida, } \\
\text { Ramanaguda, } \\
\text { Raigada }\end{array}$ & - do- \\
\hline 8. & Kalakeri & CRRI, Cuttack & - do- \\
\hline 9. & Khursudi & $\begin{array}{c}\text { Kumbharguda, } \\
\text { Kalimela, } \\
\text { Malkangiri }\end{array}$ & -do- \\
\hline 10. & $\mathrm{~N} 22$ & CRRI, Cuttack & -do- \\
\hline 11. & Padarabank & $\begin{array}{c}\text { Paluakhalia, } \\
\text { Sanakhe-mundi, } \\
\text { Ganjam }\end{array}$ & -do- \\
\hline 12. & Salkiana & CRRI, Cuttack & - do- \\
\hline 13. & Salampikit & CRRI, Cuttack & - do- \\
\hline 14. & Somo & $\begin{array}{l}\text { Hariharnagar, } \\
\text { Aska, Ganjam }\end{array}$ & - do- \\
\hline 15. & $\begin{array}{l}\text { Sahbhagi } \\
\text { dhan }\end{array}$ & CRRI, Cuttack & $\begin{array}{l}\text { Drought tolerant } \\
\text { improved var. } \\
\text { (www.crri.ac.in) }\end{array}$ \\
\hline 16. & $\begin{array}{l}\text { IR 87707- } \\
\text { 445-B-B }\end{array}$ & IRRI, Philippines & $\begin{array}{l}\text { Drought tolerant } \\
\text { donor, IRRI }\end{array}$ \\
\hline 17. & CR 143-2-2 & CRRI, Cuttack & $\begin{array}{l}\text { Drought tolerant } \\
\text { improved var. } \\
\text { (www.crri.ac.in) }\end{array}$ \\
\hline 18. & CR Dhan 40 & CRRI, Cuttack & -do- \\
\hline 19. & Anjali & CRRI, Cuttack & -do- \\
\hline 20. & Sneha & $\begin{array}{l}\text { EB-I Section, } \\
\text { OUAT, BBSR }\end{array}$ & $\begin{array}{l}\text { High yielding } \\
\text { improved variety }\end{array}$ \\
\hline 21. & Annada & CRRI, Cuttack & $\begin{array}{l}\text { Drought tolerant } \\
\text { improved var. } \\
\text { (www.crri.ac.in) }\end{array}$ \\
\hline 22. & Zhu 11-26 & CRRI, Cuttack & -do- \\
\hline 23. & Vandana & CRRI, Cuttack & - do- \\
\hline 24. & Khandagiri & $\begin{array}{l}\text { EB-I Section, } \\
\text { OUAT, BBSR }\end{array}$ & $\begin{array}{l}\text { High yielding } \\
\text { improved variety }\end{array}$ \\
\hline
\end{tabular}




\begin{tabular}{cccc}
\hline $\begin{array}{c}\text { Sl. } \\
\text { no. }\end{array}$ & Genotype & $\begin{array}{c}\text { Source } \\
\text { (Village/block, } \\
\text { district of Odisha) }\end{array}$ & Remark(s) \\
\hline 25. & Mandakini & $\begin{array}{c}\text { EB-I Section, } \\
\text { OUAT, BBSR }\end{array}$ & -do- \\
26. & Kinari & $\begin{array}{c}\text { Maharajpali, } \\
\text { Kalimela, }\end{array}$ & $\begin{array}{c}\text { Upland local land } \\
\text { race }\end{array}$ \\
27. & Pustak & Malkangiri \\
28. & Nandigiri & Baramania, \\
& & kujanga, & -do- \\
29. & Pandeydhan & Jagatsinghpur \\
& & Jharpalli, \\
Malkangiri & \\
\hline
\end{tabular}

of the $57 \mathrm{kD}$ globulin (salt soluble) polypeptide. While, the prolamin fraction is mainly composed of three distinct polypeptide groups $(10,13$, and $16 \mathrm{kD})$ (Yamagata et al., 1982). In addition, a great array of genotypic variation exists in polypeptide bands according to their electromobility on SDS-PAGE gels (Tripathy et al., 2015).

\subsection{Extent of polymorphism}

Seed storage protein profiling through SDS-PAGE for differentiating rice genotypes is well established (Thanh and Hirata, 2002). In the present investigation, SDS-PAGE of total seed storage protein revealed altogether 19 scorable polypeptide bands with molecular weights ranging from 26.0 to $123.0 \mathrm{kD}$ (Figure 1). This envisaged that at least 19 multigene families are involved in seed storage protein expression in rice. (de Lumen 1990). Out of these, four polypeptide bands at 57.0, 53.0, 51.2 and 37-39 kD were found to be monomorphic and rest of the bands had shown polymorphism to the extent of $78.94 \%$ among the test genotypes. As a whole, the resulting data matrix of the presence and absence of bands resolved a total of 338 polymorphic polypeptide bands out of total 454 bands over all the 29 test genotypes used in the study which reveals $74.44 \%$ polymorphism. Besides, a great array of polymorphism was revealed in terms of presence (1)/absence (0) of polypeptide bands as well as intensity of bands and colour of stain revealed by bands following silver staining technique in different test genotypes. The intensity of bands was given due importance while scoring of bands in different genotypes to reveal degree of quantitative variation in polypeptides dissociated following cleavage of storage protein fractions. The presence of densely stained bands was marked bold to discriminate such bands in a particular protein type or polypeptide banding pattern.

\subsection{Characteristic polypeptide banding pattern}

For ease of detection of bands, four distinct zones of polypeptide migration were arbitrarily assigned in the electrophoregram i.e. A (65.2-123.0 kD), B (53.0-60.0 kD), C (45.0-51.2 kD), D (26.0-37,39 kD). Zone A was designated by two sets of paired bands i.e., 116 and $108 \mathrm{kD}$ and 97.2 and 93 $\mathrm{kD}$; and one single fine band at $70 \mathrm{kD}$ present mostly among the test genotypes (Figure 1). Besides, it has three sparsely distributed faint fine bands at 101, 123.4 and $65.2 \mathrm{kD}$. Zone B starts with a black band at $60 \mathrm{kD}$ followed by two thick prominantly monomorphic dense yellow bands $(57,53 \mathrm{kD})$ clubbed together. Zone $\mathrm{C}$ included four faint black bands $(51.2,49.3,47$ and $45 \mathrm{kD})$ that occupied the space between yellow band at $53 \mathrm{kD}$ and a broad yellow band at $37-39 \mathrm{kD}$. Among the four bands in Zone-C, Band at $51.2 \mathrm{kD}$ is shown to be monomorphic over the test genotypes. Zone $\mathrm{D}$ is marked by a characteristic monomorphic broad dense yellow band of rice with mol. wt. 37-39 kD (37 and $39 \mathrm{kD}$ clubbed together) followed by three low molecular weight bands ranging from 28.7-26.0 $\mathrm{kD}$ in descending order.

Genetic variation in relation to presence of number of polypeptide bands in the electrophoregram ranged from 9 in

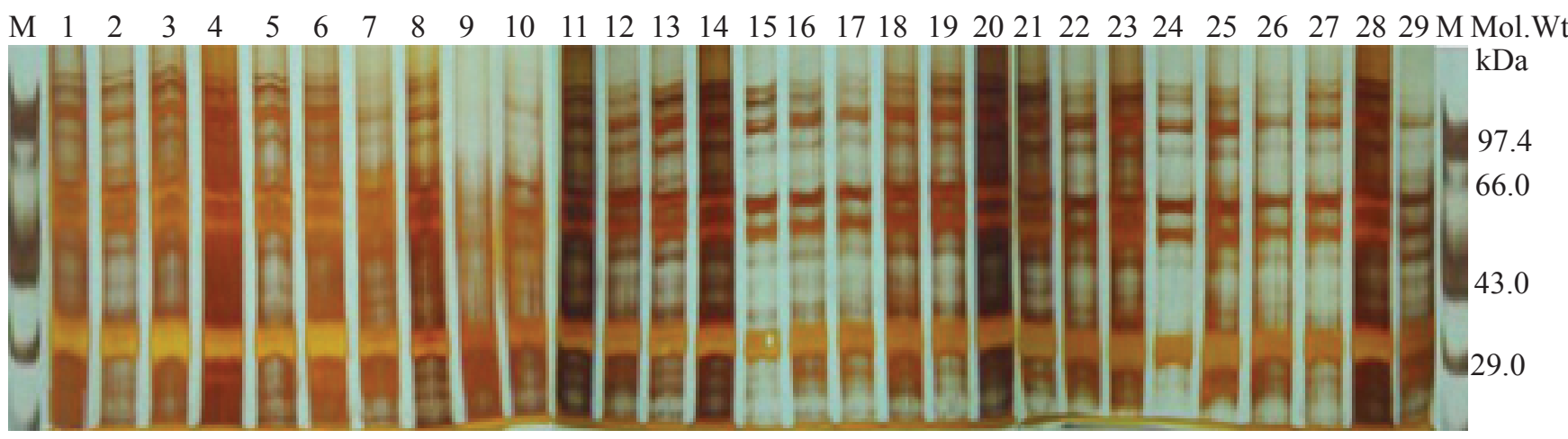

Figure 1: Total seed storage protein profile of selected local land races and promising drought tolerant donors., M-Mol. wt. marker, Lane 1-29: var. Sl. No. 1-29 (Asumakunda, Bastul, Brahmanaki, Browngora, Dular, Hiran, Kanding, Kalakeri, Khursudi, Nagina 22, Padarabank,Salkiana, Salampikit, Somo, Sahbhagidhan, IR 87707-445-B-B, CR 143-2-2, CR Dhan 40, Anjali, Sneha, Annada, Zhu 11-26, Vandana, Khandagiri, Mandakini, Kinari, Pustak, Nandigiri and Pandeydhan) 
Khursudi to as high as all 19 bands in Brahmanaki and Vandana followed by 18 bands each in case of Anjali, Asumakunda, Hiranand Padaradhan (Table 2). Besides, Nandigiri and Bastul also had higher number (17) of polypeptide bands in the electrophoregram while, Khandagiri recorded as low as only 10 polypeptide fingerprint at different molecular weight positions. Out of 19 polypeptide bands revealed in this investigation, $123.0 \mathrm{kD}, 101.4 \mathrm{kD}$ and $65.2 \mathrm{kD}$ bands were of rare occurrence over varieties in the electrophoregram. The polypeptide band at $123.0 \mathrm{kD}$ was present only in seven test genotypes. Wherepitas, $101.4 \mathrm{kD}$ and $65.2 \mathrm{kD}$ bands were observed in eight and nine genotypes respectively. Thus, bands at these above molecular weight positions may be considered as most informative and therefore, these may contribute maximum for genetic dissimilarity/genetic divergence among the test genotypes.In contrast, some researchers reported that protein composition is similar in rice with a little exception, and the composition of glutelin subunit is stable (Zhan and Lin, 1991). Others found great variations in the glutelin and/or prolamin fractions ( $\mathrm{Lu}$ et al., 2001; Jahan et al., 2003; Aung et al., 2003; Siddiqui et al., 2003).

The paired polypeptide finger prints positioned at $57.0 \mathrm{kD}$ and $53 \mathrm{kD}$ was shown to be characteristically deep/dense yellow in all the test genotypes except Khursudi and Pandeydhan which revealed blackish band. Similarly, bandsat 28.7 and $27.5 \mathrm{kD}$ which were usually faint black, but few of the test genotypes hadshown broad yellow band at these mol. wt. positions.

For instance, Hiran, Kanding and Khursudi had yellow polypeptide band at both $28.7 \mathrm{kD}$ and $27.5 \mathrm{kD}$ positions. In contrast, Browngora, Annada and Zhu 11-26 revealed yellow shaded band at $28.7 \mathrm{kD}$; and a few test genotypes e.g., IR 87707-445-B-B, CR 143-2-2, CR Dhan 40, Mandakini and Pandeydhan showed yellow colored band at $27.5 \mathrm{kD}$ only. Such

\begin{tabular}{|c|c|c|c|c|c|c|c|c|c|c|c|c|c|c|c|}
\hline Genotype & 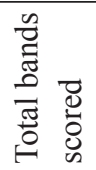 & 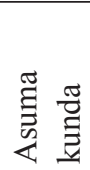 & 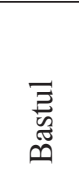 & 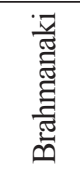 & 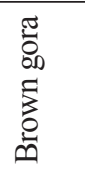 & $\frac{\vec{z}}{\vec{\Xi}}$ & 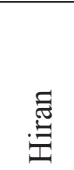 & 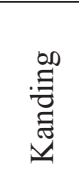 & $\frac{\bar{d}}{\frac{a}{\pi}}$ & 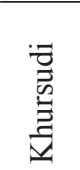 & 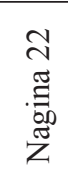 & 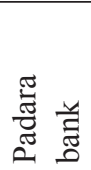 & 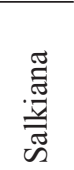 & 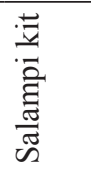 & $\begin{array}{l}\stackrel{\Xi}{0} \\
\text { ڤ̊ }\end{array}$ \\
\hline Asuma kunda & 18 & 1.00 & & & & & & & & & & & & & \\
\hline Bastul & 17 & 0.84 & 1.00 & & & & & & & & & & & & \\
\hline Bhahmanaki & 19 & 0.94 & 0.89 & 1.00 & & & & & & & & & & & \\
\hline Browngora & 16 & 0.89 & 0.84 & 0.84 & 1.00 & & & & & & & & & & \\
\hline Dular & 16 & 0.89 & 0.94 & 0.84 & 0.89 & 1.00 & & & & & & & & & \\
\hline Hiran & 18 & 0.89 & 0.94 & 0.94 & 0.89 & 0.89 & 1.00 & & & & & & & & \\
\hline Kanding & 15 & 0.84 & 0.78 & 0.78 & 0.94 & 0.84 & 0.84 & 1.00 & & & & & & & \\
\hline Kalakeri & 16 & 0.89 & 0.94 & 0.84 & 0.89 & 1.00 & 0.89 & 0.84 & 1.00 & & & & & & \\
\hline Khursudi & 9 & 0.52 & 0.47 & 0.47 & 0.63 & 0.52 & 0.52 & 0.68 & 0.52 & 1.00 & & & & & \\
\hline Nagina 22 (N22) & 13 & 0.63 & 0.68 & 0.68 & 0.73 & 0.63 & 0.73 & 0.78 & 0.63 & 0.78 & 1.00 & & & & \\
\hline Padarabank & 18 & 0.89 & 0.84 & 0.94 & 0.89 & 0.78 & 0.89 & 0.84 & 0.78 & 0.52 & 0.73 & 1.00 & & & \\
\hline Salkiana & 16 & 0.78 & 0.84 & 0.84 & 0.89 & 0.78 & 0.89 & 0.84 & 0.78 & 0.63 & 0.73 & 0.89 & 1.00 & & \\
\hline Salampikit & 16 & 0.89 & 0.84 & 0.84 & 1.00 & 0.89 & 0.89 & 0.94 & 0.89 & 0.63 & 0.73 & 0.89 & 0.89 & 1.00 & \\
\hline Somo & 16 & 0.89 & 0.84 & 0.84 & 1.00 & 0.89 & 0.89 & 0.94 & 0.89 & 0.63 & 0.73 & 0.89 & 0.89 & 1.00 & 1.00 \\
\hline Sahbhagi dhan & 16 & 0.78 & 0.84 & 0.84 & 0.89 & 0.78 & 0.89 & 0.84 & 0.78 & 0.63 & 0.73 & 0.89 & 1.00 & 0.89 & 0.89 \\
\hline IR $87707-445-B-B$ & 16 & 0.89 & 0.84 & 0.84 & 1.00 & 0.89 & 0.89 & 0.94 & 0.89 & 0.63 & 0.73 & 0.89 & 0.89 & 1.00 & 1.00 \\
\hline CR 143- 2-2 & 15 & 0.84 & 0.78 & 0.78 & 0.94 & 0.84 & 0.84 & 0.89 & 0.84 & 0.68 & 0.68 & 0.84 & 0.94 & 0.94 & 0.94 \\
\hline CR Dhan 40 & 16 & 0.89 & 0.84 & 0.84 & 1.00 & 0.89 & 0.89 & 0.94 & 0.89 & 0.63 & 0.73 & 0.89 & 0.89 & 1.00 & 1.00 \\
\hline Anjali & 18 & 0.89 & 0.84 & 0.94 & 0.89 & 0.78 & 0.89 & 0.84 & 0.78 & 0.52 & 0.73 & 1.00 & 0.89 & 0.89 & 0.89 \\
\hline Sneha & 16 & 0.89 & 0.84 & 0.84 & 1.00 & 0.89 & 0.89 & 0.94 & 0.89 & 0.63 & 0.73 & 0.89 & 0.89 & 1.00 & 1.00 \\
\hline Annada & 16 & 0.89 & 0.73 & 0.84 & 0.89 & 0.78 & 0.78 & 0.84 & 0.78 & 0.52 & 0.63 & 0.89 & 0.78 & 0.89 & 0.89 \\
\hline Zhu 11-26 & 15 & 0.84 & 0.78 & 0.78 & 0.84 & 0.84 & 0.84 & 0.78 & 0.84 & 0.47 & 0.57 & 0.73 & 0.73 & 0.84 & 0.84 \\
\hline Vandana & 19 & 0.94 & 0.89 & 1.00 & 0.84 & 0.84 & 0.94 & 0.78 & 0.84 & 0.47 & 0.68 & 0.94 & 0.84 & 0.84 & 0.84 \\
\hline Khandagiri & 10 & 0.57 & 0.63 & 0.52 & 0.68 & 0.68 & 0.57 & 0.63 & 0.68 & 0.52 & 0.52 & 0.57 & 0.68 & 0.68 & 0.68 \\
\hline Mandakini & 15 & 0.84 & 0.78 & 0.78 & 0.94 & 0.84 & 0.84 & 0.89 & 0.84 & 0.57 & 0.68 & 0.84 & 0.84 & 0.94 & 0.94 \\
\hline Kinari & 13 & 0.73 & 0.68 & 0.68 & 0.84 & 0.73 & 0.73 & 0.78 & 0.73 & 0.57 & 0.68 & 0.73 & 0.73 & 0.84 & 0.84 \\
\hline Pustak & 15 & 0.84 & 0.78 & 0.78 & 0.94 & 0.84 & 0.84 & 0.89 & 0.84 & 0.68 & 0.78 & 0.84 & 0.84 & 0.94 & 0.94 \\
\hline Nandigiri & 17 & 0.94 & 0.78 & 0.89 & 0.94 & 0.84 & 0.84 & 0.89 & 0.84 & 0.57 & 0.68 & 0.94 & 0.84 & 0.94 & 0.94 \\
\hline Pandeydhan & 14 & 0.78 & 0.73 & 0.73 & 0.89 & 0.78 & 0.78 & 0.84 & 0.78 & 0.73 & 0.73 & 0.78 & 0.89 & 0.89 & 0.89 \\
\hline
\end{tabular}


a differential banding pattern could certainly help in varietal identification and certification.

India has a rich heritage of local land races of rice and many of these have been evolved over several years in their native area of cultivation. Some of these local land races might have experienced spontaneous mutation in multi-gene families determining seed storage protein expression. Deletion of any member of these gene family or mutational changes in their regulator genes could certainly have a direct bearing on polypeptide banding pattern. In this context, Asumakunda and Hiran can be differentiated from Brahmanaki by absence of polypeptide band at $65.2 \mathrm{kD}$ and $123 \mathrm{kD}$ respectively. This signifies spontaneous mutational change in the resulting land race compared to Asumakunda and the mutational changes are hereditary and have direct bearing in total seed protein expression.

A characteristic faint blackish brown band was revealed at 60 $\mathrm{kD}$ which is reported to be the translation product of waxy (Wx) gene (Shu et al., 1999) controlling amylose content. Wei-dong et al. (2006) had shown high intensity of such $60 \mathrm{kD}$ band in high amylose content RT series mutants (RT 60, RT 61, RT 62 and RT 64) compared to the parent variety Ochikara. Hence, extent of staining intensity of $60 \mathrm{kD}$ apolypeptide marker can be used to assess amylose content. In this context, Khandagiri and a local upland land race Kinari could not reveal such polypeptide marker indicating very low amylose status. While, Asumakunda, Bastul, Brahmanaki, Kanding, Kalakeri,
Padarabank, Salampikit, Somo, CR Dhan 40, Anjali, Vandana and Pandeydhan identified to have better cooking quality (intermediate amylose content) owing to medium intensity of $60 \mathrm{kD}$ band. This phenomenon is worthwhile to study further for confirmation and validation.

\subsection{Genetic similarity/distance}

The genetic distance between genotypes suggests the relationship between the species and within the members of the same species. The crosses between parents with maximum genetic divergence are generally most responsive for genetic improvement as these can result better transgressive segregants through gene shuffling.

Similarity index (S.I.) values (Table 3 ) between each paired genotypes ranged from 0.47 to as high as 1.00 . Among the test genotypes, Khursudi (Av. S.I. $=0.58$ ) followed by Khandagiri $($ Av. S.I. $=0.62)$ and Nagina $22($ Av. S.I. $=0.69)$ had high genetic dissimilarity from most of the varieties. Khursudi maintained high genetic distance from Bastul, Brahmanaki, Zhu 11-26 and Vandana. Whereas, N22 showed appreciable genetic dissimilarity from Khandagiri and Zhu 11-26. Besides, Khandagiri was shown to be genetically distant from Asumakunda, Brahmanaki, Hiran, Khursudi, N22, Padarabank, Anjali and Vandana. Thus, the above genotypes may have merit in hybridization programme for upland situation.

In contrast, a few of the test genotypes had revealed inter se genetic homology. Sneha is a promising high yielding upland genotype. It had homology in seed protein expression

\begin{tabular}{|c|c|c|c|c|c|c|c|c|c|c|c|c|c|c|c|}
\hline Genotype & 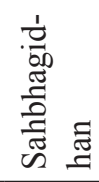 & 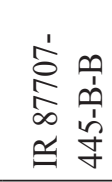 & 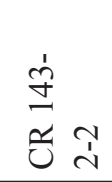 & $\begin{array}{l}\text { 壱 } \\
\text { 全 } q\end{array}$ & 言 & $\begin{array}{l}\text { 胥 } \\
\text { है }\end{array}$ & 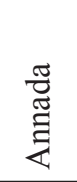 & 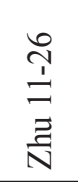 & 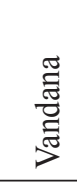 & 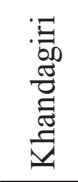 & 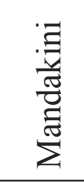 & 侌 & 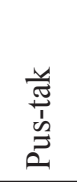 & 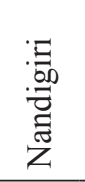 & 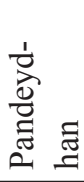 \\
\hline Sahbhagidhan & 1.00 & & & & & & & & & & & & & & \\
\hline IR 87707-445-B-B & 0.89 & 1.00 & & & & & & & & & & & & & \\
\hline CR 143- 2-2 & 0.94 & 0.94 & 1.00 & & & & & & & & & & & & \\
\hline CR Dhan 40 & 0.89 & 1.00 & 0.94 & 1.00 & & & & & & & & & & & \\
\hline Anjali & 0.89 & 0.89 & 0.84 & 0.89 & 1.00 & & & & & & & & & & \\
\hline Sneha & 0.89 & 1.00 & 0.94 & 1.00 & 0.89 & 1.00 & & & & & & & & & \\
\hline Annada & 0.78 & 0.89 & 0.84 & 0.89 & 0.89 & 0.89 & 1.00 & & & & & & & & \\
\hline Zhu 11-26 & 0.73 & 0.84 & 0.78 & 0.84 & 0.73 & 0.84 & 0.84 & 1.00 & & & & & & & \\
\hline Vandana & 0.84 & 0.84 & 0.78 & 0.84 & 0.94 & 0.84 & 0.84 & 0.78 & 1.00 & & & & & & \\
\hline Khandagiri & 0.68 & 0.68 & 0.73 & 0.68 & 0.57 & 0.68 & 0.68 & 0.63 & 0.52 & 1.00 & & & & & \\
\hline Mandakini & 0.84 & 0.94 & 0.89 & 0.94 & 0.84 & 0.94 & 0.94 & 0.89 & 0.78 & 0.73 & 1.00 & & & & \\
\hline Kinari & 0.73 & 0.84 & 0.78 & 0.84 & 0.73 & 0.84 & 0.84 & 0.78 & 0.68 & 0.84 & 0.89 & 1.00 & & & \\
\hline Pustak & 0.84 & 0.94 & 0.89 & 0.94 & 0.84 & 0.94 & 0.84 & 0.78 & 0.78 & 0.73 & 0.89 & 0.89 & 1.00 & & \\
\hline Nandigiri & 0.84 & 0.94 & 0.89 & 0.94 & 0.94 & 0.94 & 0.94 & 0.78 & 0.89 & 0.63 & 0.89 & 0.78 & 0.89 & 1.00 & \\
\hline Pandeydhan & 0.89 & 0.89 & 0.94 & 0.89 & 0.78 & 0.89 & 0.78 & 0.73 & 0.73 & 0.68 & 0.84 & 0.73 & 0.84 & 0.84 & 1.00 \\
\hline
\end{tabular}


with popular drought tolerant land races e.g., Browngora, Salampikit, and Somo and a drought tolerant donor IR $87707-$ 445-B-B (received from IRRI) with similarity value 1.00. On the other hand, Vandana-a popular upland variety under drought stress was shown to have $100 \%$ homology with a drought tolerant land race Brahmanaki.

\subsection{Clustering pattern based on total seed storage protein profile}

Seed storage protein profiling based on SDS-PAGE could be employed for various purposes, such as characterization of germplasm (Javid et al., 2004; Iqbal et al., 2005), varietal identification (Zhang et al., 1998), hybrid seed purity test (Wei-dong et al., 2006), germplasm resource analysis (Yu et al., 2003), genetic diversity analysis (Yang et al., 2005), determination of phylogenetic relationship between different species and generation of pertinent information to complement evaluation (Isemurap et al., 2001; Ghafoor et al., 2002). There have been a substantial number of studies that have used SDS-PAGE to profile seed storage proteins in rice (Netra and Prasad, 2007). Hence, it becomes highly imperative to assess genetic diversity within and between rice landraces for varietal improvement, evaluation and modification, using better methods of germplasm evaluation and characterization strategies. It is also required to investigate the present gene pool for selection of diverse parent cultivar and to broaden the germplasm base of rice breeding programs in the future for sustainable management of the genetic resources.

Electrophoretic analysis of the seed storage proteins had direct relationship to the genetic background of the proteins that reveal genetic diversity. Such analysis can be used to certify the genetic makeup of germplasm (Javid et al., 2004; Iqbal et al., 2005). The dendrogram showing genetic relationship among twenty nine test genotypes for total seed storage protein expression is presented in (Figure 2). Initially, the genotypes were distributed into three clusters. V10 (N22) and V9 (Khursudi) constituting first cluster; and V26 (Kinari) and V24 (Khandagiri) grouped together in second cluster were initially separated from rest of the genotypes which were clubbed together in third cluster at about $71.5 \%$ phenon level. However, for ease in varietal discrimination and characterization; the test genotypes were grouped into nine clusters at $90.5 \%$ phenon level. Cluster I to Cluster V were characterized as mono-genotypic as these contained single genotype each. V10 (N22), V9 (Khursudi), V26 (Kinari), V24 (Khandagiri) and V22 (Zhu 11-26) formed cluster I, II, III, IV and $\mathrm{V}$ in sequence. Thus, these genotypes could be sorted out as highly divergent genotypes for seed storage protein expression. Rest of the test genotypes were distributed over four clusters (Cluster VI-Cluster IX). Cluster VI and Cluster VII containedthree (V8-Kalakeri, V5-Dular and V2-Bastul) and
four(V29-Pandeydhan, V17-CR 143-2-2, V15-Sahbhagidhan and V12-Salkiana) genotypes respectively. While, ClusterVIII and Cluster-IX were large multivariety clusters which included ten and seven genotypes respectively. Few of the test genotypes could not be discriminated from each other at even $100 \%$ phenon level. V8 (Kalakeri) and V5 (Dular) in ClusterVI, V15 (Sahbhagidhan) and V12 (Salkiana) in Cluster-VII and V23 (Vandana) and V3 (Brahmanaki) in Cluster IX had shown common protein type owing to $100 \%$ homology in seed protein expression. It is worth to note that each of the above groups contained atleast either Dular, Sahbhagidhan or Vandana which are known to have high degree of drought tolerance and most often opted as parents for hybridization programme in many research centres. This envisaged that Kalakeri, Salkiana and Brahmanaki might be related in some way with the above respective drought tolerant genotypes and could have similar mechanism for droughttolerance. Wei-dong et al. (2006) could not differentiate all japonica varieties based on seed storage protein polymorphism. Although they had got 19 types of profile, $80 \%$ varieties showed similar polypeptide banding pattern. Jahan et al. (2003) reported nine variations of glutelin in Bangladeshi rice varieties. Aung et al. (2003) found two varietal types for glutelin, five varietal types for prolamin in Myanmar rice varieties. However, glutelin and prolamin of Pakistani rice varieties had six and four variation types respectively (Sarker and Bose, 1984).

The grouping of genotypes using three dimensional scaling based on PCA values (Figure 3). was found to be more or less consistent with that of UPGMA analysis. The three

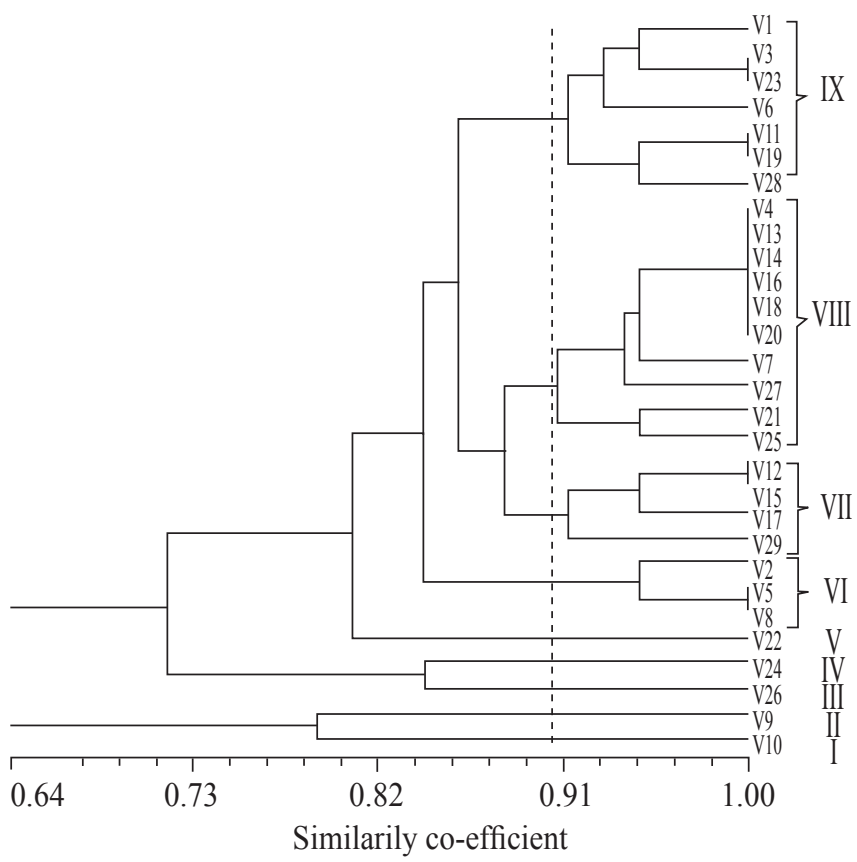

Figure 2: Dendrogram showing genetic diversity of a set of upland rice varieties based on total seed storage protein fingerprinting 


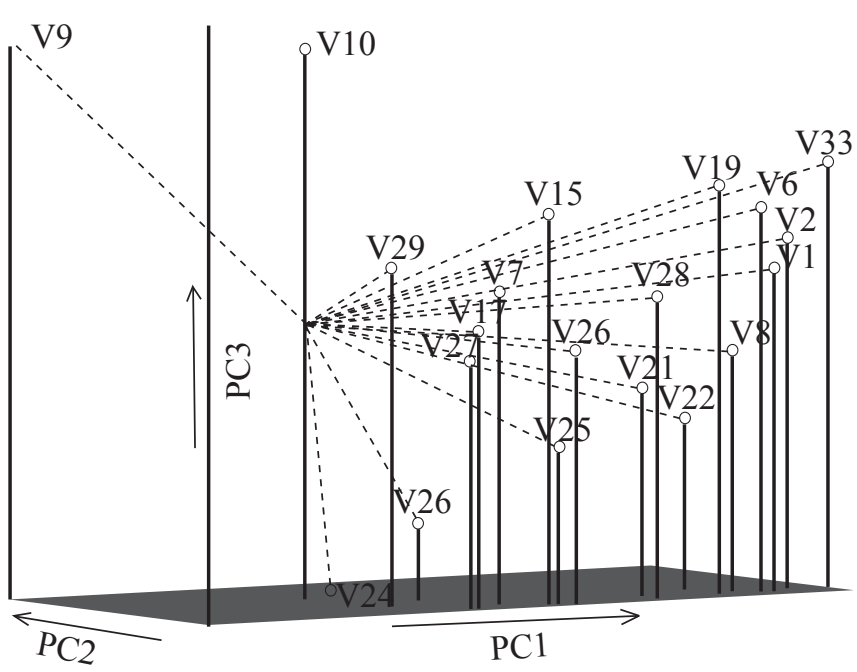

Figure 3: 3D Scaling of principal co-ordinates 1, 2 and 3 using seed storage protein markers with vectors

dimensional scaling with vectors represented clear grouping of test genotypes. V9 (Khursudi), V10 (N22), V24 (Khandagiri) and V26 (Kinari) which were initially separated from rest of the test genotypes in case of UPGMA clustering (Figure 2), were also seen to be screened out to diverse extreme positions in PCA analysis.

\section{Conclusion}

Seed storage protein profiling is a simple technique and relatively stable over environments compared to isozymes, soluble proteins and morphological traits. Therefore, it can be suitably used for genotyping in rice for varietal identification, study of genetic relationship and selection of divergent genotypes. Nagina 22, Khursudi, Kinari, Khandagiri and Zhu 11-26 have been identified as highly divergent genotypes suitable for upland condition. Drought tolerance may be introgressed into high yielding cv. Khandagiri using N22, Khursudi and Zhu 11-26 (drought tolerant) through recombination breeding.

\section{Conflict of Interest}

The authors declare that there is no conflict of interests regarding the publication of this paper.

\section{References}

Aung, P.P., Kumamaru, T., Satoh, H., 2003. Genetic variation in storage protein and storage endosperm starch in local rice cultivars of Myanmar. In: Khush, G.S., Brar, D.S., Hardy, B., (Eds.), Advance in Rice Genetics. Manila, Philippines: IRRI, 196-198.

Blum, H., Beier, H., Gross, H.J., 1987. Improved silver staining of plant proteins, RNA and DNA in polyacrylamide gels.
Electrophoresis 8(2), 93-99.

Cagampang, G.B., Cruz, L.J., Espiritu, S.G., Santigo, R.G., Juliano, B.O.,1966. Studies on the extraction and composition of rice protein. Cereal Chemistry 43, 145155.

de Lumen B.O., 1990. Molecular approaches to improving the nutritional and functional properties of plant seeds as food sources; Development and comments. Journal of Agriculture and Food Chemistry 38, 1779-1788.

Ghafoor, A., Ahmad, Z., Qureshi, A.S., Bashir, M., 2002. Genetic relationship in Vigna mungo (L.) Hepper and $V$. radiata (L.) Wilczek based on morphological traits and SDS-PAGE. Euphytica 123, 367-378.

Iqbal, S.H., Ghafoor, A., Ayub, N., 2005. Relationship between SDS-PAGE markers and Ascochyta blight in chickpea. Pakistan Journal of Botany 37, 87-96.

Isemura, T., Shiyo, N., Shigeyuki, M., 2001. Genetic variation and geographical distribution of Azuki bean (Vigna angularis) landraces based on the electrophoregram of seed storage proteins. Breeding Science 51, 225-230.

Jaccard, P., 1908. Nouvelles recherches Sur la distribution florale. Bulletin Society Vaud Science National 44, 223-270.

Jahan, M.S., Kumamaru, T., Satoh, H., Hamid, A., 2003. Genetic diversity in seed storage proteins of Bangladeshi rice cultivars. In: Khush, G.S., Brar, D.S., Hardy, B. (Eds.). Advance in Rice Genetics. Manila, Philippines: IRRI, 194-195

Javid, I., Ghafoor, A., Anwar, R., 2004. Seed storage protein electrophoresis in groundnut for evaluating genetic diversity. Pakistan Journal of Botany 36, 25-29.

Laemmli, U.K.,1970. Cleavage of structural protein during the assembly of the read of bacteriophage. Nature 227, 680-685.

Lu, Z.M., Wang, H., Shen, Y.J., 2001. Polymorphismof endosperm storage protein and application in hybrid rice (Oryza sativa L.). Journal of Nanjing Agricultural University 24(2), 6-11.

Netra, N., Prasad, S., 2007. Identification of rice hybrids and their parental lines based on seed, seedling characters, chemical tests and gel electrophoresis of total soluble seed proteins. Seed Science and Technology 35, 176186.

Ramiah, K., 1953. Rice Breeding and Genetics Scientific Monograph No.19, Indian Council of Agricultural Research, New Delhi, 3.

Ravi, M., Geethanjali, S., Sameeyafarheen, F., Maheswaran, M., 2003. Molecular marker based genetic diversity analysis in rice (Oryza sativa L.) using RAPD and SSR markers. Euphytica133, 243-252. 
Sarker, R., Bose, S., 1984. Electrophoretic characterization ofricevarieties using single seed (salt soluble) proteins. Theoretical and Applied Genetics 68, 415-419.

Sasmita, D., 2014. Genetic characterization of upland rice land races of Odisha. M.Sc. (Ag.) Thesis, Orissa University of Agriculture and Technology, Bhubaneswar, India, 93.

Sharma, S.D., Tripathy, S., Biswal, J., 2000. Origin of O. sativa and its ecotypes. In: Nanda, J.S. (Ed.), Rice Breeding and Genetics-Research Priorities and Challenges. Oxford and India Book House Publishing Company Private Limited, New Delhi, 349-369.

Shu, Q.Y., Wu, D.X., Xia,Y.W., Gao, M.W., Aryes, N.M., Larkin, P.D., William, P.D., 1999. Microsatellites polymorphism on waxy gene locus and their relationship to amylose content in indica and japonica rice, Oryza sativa L. Acta Genetica Sinica 26(4), 350-358.

Siddiqui, S.U., Satoh, H., Kumamaru, T., 2003. Variation in seed storage proteins of Pakistani rice germplasm. In: Khush, G.S., Brar, D.S., Hardy, B. (Eds.), Advance in Rice Genetics. IRRI, Manila, Philippines, 198-200.

Sokal, R.R., Michener, C.D., 1958. A Statistic Method for Evaluating Systematic Relationships. University Kansas Scientific Bulletin 28, 1409-1438.

Thanh, V.O.C., Hirata, Y., 2002. Seed storage protein diversity of threerice species in the Mekong Delta. Biosphere Conservation 4, 59-67
Tripathy, S.K., Mohapatra, B.R., Nayak, P.K., Pal. S., Senapati, N., Dash, G.B., Lenka, D., Swain, D., Ranjan, R., 2015. Revealing genetic variation in upland rice using seed storage protein profiling. Research on Crops 16(2), 320-331.

Wei-dong, J., Na, Li., De-lin, H., 2006. Genetic diversity of seed storage proteins in different ecotype varieties of japonica rice and its application. Rice Science 13(2), 85-92.

Yamagata, H., Sugimoto, T., Tanaka, K., Kasai, Z., 1982. Biosynthesis of storage proteins in developing rice seeds. Plant Physiology 70, 1094-1100.

Yang,T.Y., Shen, Y.H., Huang, X.G., He, J.H., Wu, G.Z., 2005. Identification of genetic diversity in the foxtail millet (Setaria italic L. Beauv.) by A-PAGE. Acta Agronomica Sinica 131(1), 131-133.

Yu, C.M., Chen, P.D., 2003. Study on common wheat (T. aestlvum L.) germplasm for waxy protein. Journal Nanjing Agricultural University 26(3), 1-6.

Zhan, X.Y., Lin, R.H., 1991. Electrophoresis analysis on glutelin of cultivar rice and wild rice. Chinese Journal of Rice Science 5(3), 109-113.

Zhang, C.Q., Yin, Y.P., Gao, R.Q., Jia, J.Z., 1998. Polymorphism of seed protein and identification of cotton cultivar. Scientia Agricultura Sinica 31(4), 16-19. 